\title{
Raba tujk v mariborskih govorjenih medijih
}

\author{
Alenka Valh Lopert \\ Univerza v Mariboru, Filozofska fakulteta, Koroška cesta 160, \\ SI-2000 Maribor, alenka.valh@uni-mb.si
}

\begin{abstract}
$\mathrm{V}$ prispevku so predstavljene tujke, ki jih uporabljajo poklicni govorci pri neposrednem in pri reproduktivnem ubesedovanju na dveh radijskih postajah v Mariboru, in sicer na nacionalni Radio Maribor in komercialni Radio City. Analiziranih je bilo skupaj 34 govorcev, besede so opredeljene glede na izvor, podrobneje pa glede na možnost rabe slovenskih ustreznic.
\end{abstract}

This article examines the foreign words used by professional announcers in their prepared and non-prepared (spontaneous) speech on two radio stations in Maribor, the national broadcaster (Radio Maribor) and the commercial channel (Radio CITY). The analysis includes 34 speakers; the words were defined according to their etymology and their possible Slovene equivalents.

Ključne besede: slovenščina, jezik medijev, tujke, Radio Maribor, Radio City

Key words: Slovene language, Language of media, foreign words, Radio Maribor, Radio City

\section{0 medijih}

Obstajajo različne definicije medijev. V etimološkem smislu so mediji najprej posredniki sporočil, katerih izvor je ena, cilj pa druga domena komunikacije (Granić 2006: 267-278). Prenašajo sporočila in demokratizirajo kulturo, prenašajo svetovni nazor, politiko, zato tudi pravimo, da globalni mediji tvorijo globalno kulturo. Državni zbor Republike Slovenije je leta 2001 sprejel Zakon o medijih. ${ }^{1}$ Ta namreč določa pravice, obveznosti in odgovornosti pravnih in fizičnih oseb ter javni interes Republike Slovenije na področju medijev. V 1.

${ }^{1}$ Zakon o medijih: Uradni list 35/2001, 11. 5. 2001 (stran 4017). Dostopno oktobra 2009: http://www.uradni-list.si/1/objava.jsp?urlid=200135\&stevilka=2043. 
poglavju (Skupne določbe), 1. oddelku (Uvodne določbe), v 2. členu opredeljuje, da po tem zakonu mediji so:

(1) časopisi in revije, radijski in televizijski programi, elektronske publikacije, teletekst ter druge oblike dnevnega ali periodičnega objavljanja uredniško oblikovanih programskih vsebin s prenosom zapisa, glasu, zvoka ali slike, na način, ki je dostopen javnosti. (2) Programske vsebine po tem zakonu so informacije vseh vrst (vesti, mnenja, obvestila, sporočila ter druge informacije) in avtorska dela, ki se razširjajo prek medijev z namenom obveščanja, zadovoljevanja kulturnih, izobraževalnih in drugih potreb javnosti ter množičnega komuniciranja.

Klasifikacije medijev so različne: tiskani (knjige, periodika), elektronski (radio, televizija) so stari oz. klasični mediji; novi so splet, elektronska pošta, sms-sporočila itd. Medij predstavlja konkretizacijo, tj. materialno podstat, brez medijev bi jezik ostal na ravni konstrukta, tj. abstraktni sestav. J. Granić (2006: 268) navaja, da medij ni nevtralen, že sam je sporočilo, in povzema McLuhana in Hymesa, da je govor sporočilo, jezik pa kod, ter Škiljana, da je medij kanal, od katerega je odvisen diskurz. Zato tudi trditev, da je jezik v službi medijev, ki imajo glavno vlogo pri sklepanju kompromisov ali vsaj iluzijo o tem, da se spoštujejo pravila in norme. Pomembni so, ker je od njih odvisna tudi percepcija nas samih, niso statični, nikoli ne »spijo«, nas nadzirajo, kdo, kdaj in kaj bo rekel (Granić 2006: 276). Zato raziskovalci imenujejo radio nesporno drugotno občilo (Kosi 2000: 6), pa tudi najhitrejši medij (Pivec 2005: 55). Ob številnih sodobnih elektronskih medijih se zastavlja vprašanje, ali je radio kot medij še aktualen. Vendar pa pojavljanje novih radijskih postaj (predvsem lokalnih, komercialnih) kaže na porast le-teh, v ZDA, recimo, od leta 1980 za 22 \% (Barlett 1995, po Zgrabljić Rotar 2007: 22). Za to so (Zgrabljić Rotar 2007: 22-23) pomembni naslednji dejavniki: 1. poslušanje radia je del množične kulture in je medij govora, pri čemer je poslušalec aktiven soudeleženec, saj si podobo/sliko poročane situacije ustvarja sam; 2. poslušajo ga prebivalci različnih starosti; 3. radio omogoča identifikacijo s skupino in vključenost v družbo; 4. mlajši (14-16 let) poslušajo večinoma glasbo; 5. starejši pa informativne oddaje, in sicer zaradi občutka vključenosti in pripadnosti družbi; 6. radio je po McLuhanu hladen medij; ${ }^{2}$ 7. radio lahko hitreje od časopisa in televizije prenese novice; 8. programsko je raznolik in sorazmerno lahko in hitro pokriva različna po-

${ }^{2}$ I. Škarić ločuje (po McLuhanu) medije na tople in hladne. Med prve prišteva tiste, ki zaposlujejo eno čutilo $\mathrm{z}$ mnogo informacijami in prinašajo dosti podatkov, to so fotografija (ker so pri fotografiji vse točke označene in tako informativne), film (ker ga gledamo v kinodvorani in smo pozorni le na platno), telegraf, pismo; med druge pa tiste, ki ne prinašajo dosti podatkov, to so risba (saj je večina polja neizpolnjena in tako neinformativna), strip, risani film, telefon, televizija (ker se okoli ekrana dogaja še mnogo stvari in nismo osredinjeni le na gledanje) in govor. Govor ima naslednje značilnosti hladnega medija: je multisenzoričen, poteka $\mathrm{v}$ odprtem prostoru, je širokega spektra, ima veliko zvočno dinamiko, je nepopravljiv, prekinjan $\mathrm{z}$ odmori, ritmičen, beseda $\mathrm{v}$ govoru je večpomenska, ima konotativen pomen in vzbuja asociacije. Kot hladen medij je torej nedorečen in zelo aktivira prejemnika (poslušalca, sogovorca) (Škarić 1982: 24). 
dročja družbenega in zasebnega življenja prebivalcev; 9. radio nima le vloge informiranja, ampak tudi povezovanja in pripadnosti; 10. radio ni drag medij.

\section{Radio kot dejavnik spreminjanja jezika}

Javni govorci, ${ }^{3}$ kot so učitelji, politiki, duhovniki, govorci na raznih javnih prireditvah in posebej govorci na radijskih in televizijskih postajah bi v skrbi za zborno izreko morali uporabljati ustrezne priročnike. ${ }^{4}$ Družba je namreč vedno bolj govorno usmerjena in tudi v poslovnem svetu je vedno bolj v ospredju govorno sporazumevanje. Na slovenskem jezikoslovnem področju se $\mathrm{z}$ analizo jezika $\mathrm{v}$ govorjenih medijev (radio, televizija, SMS-sporočila in računalniški klepeti kot nadomestki telefonskih pogovorov) $\mathrm{v}$ zadnjih letih $\mathrm{v}$ več raziskavah ukvarjajo: H. Tivadar, ${ }^{5}$ L. Kosi, S. Kranjc, M. Kalin Golob, J. Zemljarič Miklavčič, T. Verovnik, I. Orel, A. Žele, A. Valh Lopert. Za analize jezika medijev so večinoma izbrane t. i. informativne oddaje, torej novinarske oddaje, pisane ali samo govorjene, ter nekatere govorno-glasbene oddaje, medtem ko so umetniške (t. i. režirane) neobdelane. Jezikoslovci na problematiko kulture govora $v$ medijih gledajo različno, nekateri zagovarjajo zborni jezik na radiu, drugi sproščenost in s tem odmik od zbornega jezika. Primer za prvo trditev najdemo v Sloveniji že leta 1977 (Kaluža 1977/78: 21-23), ko so v govoru na Radiu Ljubljana ugotavljali razmerje med zbornim jezikom, pogovornim jezikom in narečjem, s tem si radijski program prizadeva biti govorno čim bolj živ in neposreden. Za vse brane oddaje je veljalo, da »po zasnovi terjajo zbornost govora«. Vendar je bila zbornost velikokrat »nefunkcionalno kršena z nezbornim govorom « (Prav tam). Pogovorni jezik in narečje pa lahko delujeta funkcionalno, če sta npr. krajevno ali socialno motivirana (pogojno je narečni izgovor opravičljiv in funkcionalen pri novinarjih dopisnikih, če je pokrajinsko in položajsko motiviran).

${ }^{3}$ V. Mildner (1998: 349-366) je raziskovala odnos do hrvaških govornih variant v 15 mestih. V večini je bil odpor do Zagreba povezan tudi z odporom do jezika, kakršnega govorijo v Zagrebu. Anketirani so bili študenti FF v Zagrebu. Na lestvici 1-7 so morali oceniti 12 trditev o tem, ali je govor nekega mesta - lastnega in drugih - primeren za govor v medijih ali za učitelja/zdravnika/trgovca. Rezultati, ki nas zanimajo, so naslednji: vprašani so bili najbolj tolerantni do rabe variant jezika v lokalni rabi, najmanj pa v sredstvih javnega obveščanja, kot sta radio in TV. Prav tako lokalnega govora ne dopuščajo pri učitelju, nekoliko še tolerirajo zdravniku, najbolj pa trgovcu.

${ }^{4}$ Novejših priročnikov za govorjeno slovenščino, žal, ni prav dosti. Leta 2003 sta lektorici govorjenega jezika C. Šeruga Prek in E. Antončič izdali priročnik Slovenska zborna izreka, ki se opira na obe temeljni deli slovenskega knjižnega jezika, to sta Slovenska slovnica 2000 in Slovenski pravopis 2001.

${ }^{5}$ Prim. Tivadar 2008: 24-35. 


\section{Tujke in purizem}

J. Toporišič je že leta 1971 (2006: 62-63) uvedel pojem prevzeta prvina in jo opredelil kot (Toporišič 1992: 218) besedo, ki se v kateri jezik dobi iz kakega drugega jezika (ali v knjižni jezik iz kakega narečja istega jezika) - lahko gre za občno ime (sposojenka, če je jeziku prevzemalcu povsem prilagojena; če ni, ji pravimo tujka (Toporišič 1992: 334) ali lastno ime (podomačena, polcitatna imena); za izposojenko (1992: 68) je uvedena kazalka na sposojenka (299): beseda (besedna zveza), ki je prišla iz drugega jezika in je popolnoma prilagojena zgradbenim lastnostim prvin slovenskega (knjižnega) jezika. M. Snoj (2005: 113-122) pa opredeljuje izposojenko kot besedo, ki jo je preprosto ljudstvo prevzelo iz sosednjega narečja tujega jezika $\mathrm{v}$ svoje narečje, pri tem gre za prenos iz govorjenega $\mathrm{v}$ govorjeni jezik. Tujko pa mu predstavlja tista beseda, ki jo je izobraženec prevzel v svoj knjižni jezik iz tujega knjižnega jezika, pri čemer jezik ni nujno sosedski, prenosnik pa je pisni. Prevzete besede vstopajo v slovenski jezik na več načinov: (a) v neknjižni jezik (npr. pogovorno okej za angl. $O . K$.); (b) v knjižni jezik stopijo kot strokovni izrazi, se pa prilagodijo slovenskemu izgovoru in zapisu (code > koda, kod); (c) potisnjene so na raven pogovornega jezika, a živijo ob knjižnem izrazu, ki je bil za knjižno rabo pravočasno in ustrezno tvorjen (grapefruit > grenivka; bedge > priponka). Pri prenosu iz tujega jezika pa prihaja do semantičnih premikov na različnih nivojih: (a) ničta pomenska širitev, tj. pomen ostane nespremenjen glede na pomen tujke; box > boks (po Sicherl 1999: 144 še biftek, bridž, kilt, pulover, poker, taksi, hipi); (b) oženje pomena, tj. besedo prevzamemo le v enem tujem pomenu: hobby > hobi 'imeti hobi/konjiček; imeti kaj za hobi v prostem času' (za angl. '1. hobby (sam.) hobi, konjiček; arch konjiček; hist zgodnji tip dvokolesa; majhen sokol lovec; 2. hobby (glag.) imeti hobi; imeti kaj za hobi' (po Sicherl 1999: 144 še puding, štrajkati); (c) širitev pomena, tj.: bar > bar v slovenščini 'nočni lokal'; večinoma pa posplošena raba za 'lokal, kjer se alkoholne pijače pijejo stoje' za angl. 'nočni zabavni lokal z glasbo in artističnimi točkami'. ${ }^{6}$

Dodati je treba, da je prenosnik bil v začetku res pisni, $v$ današnjem času hitrega prenosa informacij pa je to nedvomno tudi ali zlasti govorjeni jezik. Jezik namreč razkriva, kaj smo in kaj želimo biti, zato nas lahko združuje in tudi ločuje. Kaže pripadnost govorca družbi, ločuje posamezne skupnosti, ki oblikujejo svojo govorico (pripadniki manjših skupin, kot so družina, pari, sostanovalci, poklicne skupine ...). Prav o pomenu socialnega konteksta piše tudi M. Orožen (2003: 216-233), avtorica posega v preteklost in pojasnjuje razloge za spremembo podobe slovenskih govorov konec 20. st. zaradi izumiranja in izseljevanja prvotnega vaškega prebivalstva, dnevnih migracij v industrijska in mestna središča, drugih načinov dela na podeželju, izginjanja rokodelskih poklicev, vpliva »prestižnega govora« šole, cerkve, RTV. Prevzetih besed je bilo vedno več, in sicer v meščanski kulturi napol ponemčenih mest, v strokovni

${ }^{6}$ Več glej: M. Kalin Golob 2008: 32-34; E. Sicherl 1999: 144-145. 
terminologiji, v obrteh. Zato so bila ob narodni ogroženosti antigermanska puristična gibanja razumljiva (Bezlaj 1967: 34-35). Vendar pa kljub temu ne moremo omejiti vplivanja tujih (zlasti sosednjih) jezikov, ki se nadaljuje tudi v knjižni jezik.

Claude Hagege (2005: 96, 119-124) med pomembne težave jezikov (tudi razloge za izumiranje jezika) na eni strani omenja pomanjkanje prestižnosti jezika, na drugi pa puristično strogost. V Enciklopediji slovenskega jezika (Toporišič 1992: 239) je purizem opredeljen kot »negativno razmerje do (po nepotrebnem) prevzetega ali do prevzemanja iz enega (t. i. prevladnega) jezika $\mathrm{v}$ drugega (sprejemalnega)«. Na Slovenskem (Kalin Golob 2008: 11-40) je doživel različne razvojne stopnje, od t. i. zmernega, pozitivnega oz. konstruktivnega, pri katerem jezikovnokulturno prizadevanje teži k vzdrževanju jezikovnih pravil, narejenih zaradi ohranitve jezika in njegove samobitnosti (T. Korošec 1985), do skrajnega, negativnega, zaviralnega, ki preganja besede samo zaradi njihovega izvora (germanizmi, romanizmi, anglizmi ...), za katere nimamo ustreznih slovenskih, to pa nedvomno vodi v siromašenje jezika (Kalin Golob 2008: 19). Še ožje in strožje posege v jezik pa zagovarja t. i. puristična strogost (Hagege 2005: 96), pri kateri je jezik privzdignjen za obredne namene in nastopa že kot muzejski fosil, torej ga v vsakodnevnem govoru ni več. S slovenskim purizmom se znanstveno ukvarja tudi kanadski jezikoslovec G. Thomas (1991: 58), ki poudarja, da nikakor ne gre le za slovenski pojav. Purizem mu namreč predstavlja željo po ohranjanju danega jezika in njegovega prestiža, obravnava pa kar sedem vzorcev (1991: 158-159): obroben (marginal), grajajoči (trimming), razvojni (evolutionary), nihajoči (oscillatory), stalni (stable, consistent), revolucionarni (revolutionary) in zmerni (moderate, discontinuous). ${ }^{7}$ Slovenskega (kot madžarskega, finskega, estonskega, hebrejskega, hrvaškega) Thomas (1991: 159) uvršča v vzorec razvojnega purizma, ki je nastal kot »vrednostni pojav zgodaj v razvoju knjižnega jezika, ni izpostavljen radikalnim spremembam v usmeritvi in svoj vrh doseže med standardizacijo ter se sprosti, ko knjižni jezik doseže avtonomnost, prestiž in varnost polne rabe «. ${ }^{8}$ To pa predstavljajo slovnica, slovar in pravopis.

\section{Raba tujk $v$ jeziku radia}

Glede na druge medije je radio zelo razširjen in poslušan. Če ga primerjamo s televizijo ali s časopisom, lahko ugotovimo, da imamo na televiziji na voljo tudi sliko, v časopisu lahko večkrat preberemo, na radiu pa imamo samo izginjajoč glas. Zato tudi poslušalec ne more sprejeti več ali bolj kompleksnih sporočil hkrati. To je tudi razlog, zakaj mora biti jezik govora radia jasen in razumljiv.

${ }^{7}$ Slovenska poimenovanja šestih so zaradi težnje po enotni terminologiji prevzeta po M. Kalin Golob (2008: 18). V prevodu je dodan zmerni (moderate, discontinuous) purizem.

${ }^{8}$ Prevod po: Kalin Golob 2008: 19. 
Zato prispevek prinaša analizo neposrednega in reproduktivnega ubesedovanja na vzorcu 34 govorcev dveh radijskih postaj v Mariboru, in sicer glede na rabo tujk. Gre za nacionalno postajo radio Maribor in za komercialno radijsko postajo City. V prvem sklopu (a) so besede raziskane glede na izvor po Slovenskem etimološkem slovarju M. Snoja (dalje SES), ki ustreza potrebam prikaza in odpira možnost natančnejše analize po Etimološkem slovarju slovenskega jezika F. Bezlaja; če besed po izvoru ni bilo moč najti v SES, je ta potrjen v drugih (dvojezičnih slovarjih: angleško-slovenski, nemško-slovenski in italijansko-slovenski) in v Slovarju tujk. Primer: ali so k nam prišle iz/prek sodobnih evropskih jezikov: angl. Radar: Ra(dio) D(etecting) A(nd) R(anging); nem. stadion: das Stadion; fr. solidaren: solidaire (iz lat., in solido 'v celoti') ...; iz lat./gr. lat. studio: 'delovna soba, učilnica', gr. telefon: tele 'daleč' in phone 'glas'. V drugem, osrednjem, pa je predstavljeno besedje z vidika (b) možnosti ustreznega slovenskega izraza, saj so slovenske ustreznice v zadnjem veljavnem slovenskem normativnem priročniku (Slovenski pravopis 2001, dalje SP 2001) razdeljene v naslednje skupine: nevtralna ali navadnejša dvojnica, enakovredna domača vzporednica prevzeti besedi, manj navadna domača vzporednica prevzeti besedi in kot splošna pomenska uvrstitev. ${ }^{9}$

Prispevek skuša na eni strani pokazati na vpetost prevzetih besed in besednih družin v slovenski jezikovni sistem, na drugi pa na možnosti ustreznega slovenskega izraza in s tem krepitve jezikovnega občutka.

\subsection{Analizirano gradivo glede na izvor besed}

Popis prinaša pregled besedja, izbranega iz posnetega gradiva spontanega in reproduktivnega govora na Radiu City in Radiu Maribor, pri čemer ni zajeto stilno zaznamovano prevzeto besedje (fajn, faliti, fejst, filati, fraj, ful, ibercuk, kul, magari, okej, pasati, pir, probati, pubec, rogoviliti, rabiti, rufnem, šalter, šlatati, šparati, špil, štimati, šoder, šoping, šov, tepih, usran, ziher ...), ki pa je bilo $\mathrm{z}$ vidika stilne zaznamovanosti obravnavano v drugih prispevkih. ${ }^{10}$

V tej analizi so zajete le tujke, kot jih opredeljuje M. Snoj, in sicer da jih je »/.../ izobraženec prevzel v svoj knjižni jezik iz tujega knjižnega jezika«.

4.1.1 Iz francoščine: aerodrom: aerodrome 'tekališče', 'letališče'; a propos: frc. cit.: 'ravno prav; saj res; pa še to'; debatirati: glag. debattre 'debatirati,

\footnotetext{
${ }^{9}$ SP 2001: člen 1063: ležeče sopomenka v ležečem tisku brez oklepaja zaznamuje v knjižnem jeziku nevtralno ali navadnejšo dvojnico: plán - a $m$... načrt; súbstantiv - a $m$... samostalnik; (ležeče) sopomenka v ležečem tisku v okroglem oklepaju zaznamuje enakovredno domačo vzporednico prevzeti besedi: dialektologíja ... (narečjeslovje); $<$ ležeče > sopomenka v ležečem tisku v lomljenem oklepaju zaznamuje manj navadno domačo vzporednico prevzeti besedi: brikét ... < stisnjenec $>$; |pokončno| splošna pomenska uvrstitev, npr.: bájen -jna -o ... poud. a pokrajina |nenavadno lepa, čudovita|.

${ }^{10}$ Prim. Valh Lopert, 2007; 2008.
} 
diskutirati', prvotno '(besedni) boj'; ekipa: equipe 'opremiti ladjo z moštvom', 'moštvo; skupina'; ekranizirati: (za sam. ekran) ecran 'ekran', za starejše 'zaslon pri pečici'; parlament: parlement 'parlament, skupščina'; premier: premier 'prvi, najpomembnejši, glavni minister'; resor/resorsko/(med)resorsko: ressort 'vzmet, gonilna sila; področje, delovno področje, stroka, posel, pristojnost'; organizirati: organiser 'prirediti, urediti'.

4.1.2 Iz oz. večinoma prek nemščine: adaptacija: prek nem. adaptieren iz lat. adaptare 'prilagoditi, prirediti'; agencija: po zgledu nem. Agent, Agentie, Agentur, frc. agent, agence iz lat. agens 'ki deluje, dela, poganja'; absolutno: po zgledu nem. absolut iz lat. absolūtus 'dovršen, popoln'; agresor: prek nem. Aggression, aggresiv, Aggressor iz lat. aggressio 'napad'; aktualen: prek nem. aktuell 'pomemben za sedanjost, dejanski'; [nlat. actualis iz lat.]; atentat: prek nem. Attentat iz frc. attentat 'napad, atentat'; apatičnost: po zgledu nem. Apatie iz gr. apátheia 'neobčutljiv, stoičen'; aretirati: prek nem. arretieren 'zapreti, aretirati' iz vlat. arrestūre 'ustaviti'; blamirati se: prek nem. blamieren (iz fr. Blamer, prek lat. iz gr.); debatirati: prek nem. die Debatte iz frc. glag. debattre 'debatirati, diskutirati'; demonstrirati/demonstracije: prek nem. Demonstration iz lat. demonstrare iz lat. monere 'opozarjati, svariti'; delegacija: prek nem. Delegat) iz lat. dēlēgātus 'pooblaščenec, odposlanec'; disciplina: prek nem. Disziplin, iz. lat. disciplīna 'nauk, učni predmet'; ekspedicija: prek nem. Expedition, iz lat. expedītio 'vojaški pohod, odprava'; ekstremen/ekstremno: prek nem. Extrem 'skrajnost' iz lat. extremus 'najbolj zunanji'; etnija: prek nem. ethnisch iz gr. éthnos 'pleme, narod'; faktor: event. ${ }^{11}$ prek nem. Faktor iz lat. factor 'kdor nekaj dela'; fantastičen: event. prek nem. za sam. Phantasie iz lat. phantasia (prvotno torej 'misel, privid'); film: event. prek nem. Film iz angl. 'film'; fleksibilen: prek nem. flexibel 'fleksibilen, elastičen, prilagodljiv, spremenljiv'; funkcija: prek nem. Funktion iz lat. functio 'opravljanje dela, dolžnosti'; grafik: po zgledu nem. Graphik, iz gr. graphikế 'slikarstvo'; hipodrom: po zgledu nem. Hippodrom in frc. hippodrome iz gr. hippódromos 'dirkališče za konje'; idila: prek nem. Idylle) iz lat. īdyllium 'pastirska pesem'; ilustrator: prek nem. Illustration, illustrieren iz lat. illūstrātio 'osvetlitev'; informativen: prek nem. (za sam.) Information iz lat. informāre 'upodobiti, predstaviti'; interesanten: prek nem. interessant, Interesse, iz. lat. interessens 'biti zraven, pri stvari, prisoten'; 'zanimiv'; kariera: prek nem. die Karriere 'poklicna, življenjska pot' iz lat. carrus 'kolovoz, cesta'; karakter: prek nem. Charakter, iz g. kharaktếr 'značajska poteza'; katastrofalen: prek nem. Katastrophe in lat. catastropha iz gr. katastrophế 'uničenje, poguba'; kolegij: event. prek nem. Kollege iz lat. collēga 'delavec, tovariš'; komentirati: prek nem. kommentieren iz lat., commentārī 'premisliti, preudariti, preučiti'; kompleks: event. prek nem. Komplex iz lat. complexus 'prepleten'; komunikacija: prek nem. kommunizieren iz lat. communicāre 'sporočiti, posvetovati se'; konflikt:

${ }^{11}$ event. za eventualno: mogoče, morebiti 
po zgledu nem. Konflikt iz lat. conflictus 'spopad, udar'; konkurenčnost: prek nem. konkurrieren iz lat. concurrere 'skupaj teči, (sovražno) skupaj trčiti'; kvaliteten: prek nem. Qualitat iz lat. qualitas 'kakovosten'; kvintet: event. prek nem. Quintett, iz lat. quinque 'pet'; lokacija: prek nem. Lokation iz lat. locātio 'določeno mesto'; novela: event. prek nem. Novelle iz it. novella, dobesedno 'novica'; iz lat. novellus 'nov, novcat'; operativen: prek nem. operativ 'operativen' iz lat. operatīvus 'dejaven'; orientacija: prek nem. orientieren iz frc. orienter, izposojeno iz lat. oriens 'vzhajati, nastajati' orientation 'orientacija, usmerjenost'; organizirati: prek nem. organisieren iz fr. organiser ' urediti; dobiti, priskrbeti'; originalen: prek nem. original iz lat. originale 'prvoten, izviren'; parlament: event. prek nem. Parlament, iz frc. parlement 'parlament, skupščina'; partner: event. prek nem. Partner iz angl. partner iz lat. partiōnārius 'družabnik'; policist: prek nem. Polizei, Polizist iz srlat. policia 'državna uprava, oblast'; profesionalen: prek nem. professionell, iz franc., iz lat. professio 'obrt, stroka'; produkt: prek nem. Produkt, produzieren (angl. product), iz lat., prōductum 'kar je narejeno, ustvarjeno'; profesorica: prek nem. Professor iz lat. professor 'javni učitelj, profesor'; redakcija: nem. die Redaktion, 'uredništvo'; realizacija: nem. realisieren 'izpeljati/izpolniti/uresničiti'; reforma: prek nem. (za glag.) reformieren iz lat. reformāre 'preoblikovati'; regija: prek nem. Region iz lat. regio 'krajina, kraj, meja'; režim: event. prek nem. Regime, iz frc. ragime 'režim, oblika vladanja' iz lat. regimen 'vodstvo, uprava, vlada'; rubrika: prek nem. Rubrik 'razpredelek', iz lat. rubrīca, ruber do 'prostor, ki ga zavzema besedilo enega zakona'; servis: prek nem. Service iz frc. service 'servis, postrežba, služba, posel' iz lat. servitium 'uslužnost'”v delavnico'(ni v pomenu 'služba'); simfonik: prek nem. Symphonie, iz lat., iz gr. symphonía 'soglasje'; socialističen: prek nem. sozial iz lat. sociālis 'družben, tovariški'; solidárnosten: event. prek nem. solidalisch iz fr. solidaire, iz lat., in solido 'v celoti' složen, povezan; solo: event. prek nem. solo iz lat. solus 'sam, edin'; spektakel: prek nem. Spektakel iz lat. spectaculum 'prizor, pogled, gledališče'; stadion: iz nem. Stadion 'prostor za športne igre' iz grš. stádion 'tekmovalna steza'; status: iz nem. Status iz lat. status 'stanje, drža, razmere'; studio: prek nem. Studio, angl. studio iz lat. studio 'delovna soba, učilnica'; termin: iz nem. Termin; iz lat. terminus 'mejnik, skrajna točka'; temperatura: prek nem. Temperatur iz lat. temperātūra 'toplota'; univerziteten: prek nem. Universität iz lat. ūniversitas 'združenje profesorjev in študentov'.

4.1.3 Iz angleščine: bejbi: baby 'otročiček, dojenček'; blok: (apartment) bloc za slov. blok 'zgradbo z več stanovanji'; blues: blues; donacija: donate 'podariti, darovati'; fenomenalen: phenomenal 'fenomenalen, čudovit, sijajen, nenavaden'; hit: 'popularna popevka'; impresije: impression 'impresija; vtis'; internet: 'medmrežje'; manager prek angl. 'upravnik, upravitelj, vodja, oskrbnik, gospodar; direktor, poslovodja' izposojeno iz fr. ménage 'voditi, vladati'; kreativen: creative 'stvariteljski, ustvarjalen, stvarljiv, tvoren, ploden'; mejl: mail 'pošta'; radar: Ra(dio) D(etecting) A(nd) R(anging) 'odkrivanje in ugotavljanje predmetov'; rap: 'bitovska zabavna glasba'; rokenrol: rock'n'roll 'rok'; 
singel: single 'posamezen, poedin; enojen'; startati: start 'začeti'; šov (show gl. šov) show 'pokazati; predstava, revija'; terminal: terminal 'končna postaja'; vikend: weekend 'konec tedna'.

4.1.4 Iz drugih evr. jezikov, in sicer iz: avizo: špan. aviso iz ital. 'uvodna najava'; apatičnost: gr. apatheia; 'neobčutljiv, stoičen'; čao: it. arrivederci, ciao 'zbogom'; fluktuacija: nlat. fluctuatio 'spreminjanje, gibanje česa'; inženíring: prek frc. ingénieur iz it. ingegnere iz lat. ingignere 'inženirec, strokovnjak za gradnjo', mikrofon: iz gr. mīcrós 'majhen' in phōnế 'zvok'; monsinjor: nlat. 'zaslužni duhovnik'; sold (šold): vlat. soldus, iz klas. lat. solidus 'zlatnik'; telefon: iz gr. tễ le 'daleč' in phōnế 'glas'; televizija: iz gr. tễ le 'daleč' in visio 'pogled'.

\subsection{Analizirano gradivo glede na slovenske ustreznice}

Besedje je razvrščeno glede na štiri sklope slovenskih ustreznic, ki jih ponuja Slovenski pravopis (2001).

4.2.1 Označeno samo kot ležeče, ki pomeni nevtralno ali navadnejšo dvojnico: absolutno: nesporno, popolno, vsestransko; adaptacija: prilagoditev, prilagajanje; aerodrom: letališče; agresor: napadalec; aktualen: zanimiv, sodoben, dejanski; apatičen: brezvoljen, top, apatičnost brezvoljnost, topost; blamirati se: osramotiti se osmešiti se; ekipa: moštvo, skupina; demonstracija: predstavitev, prikaz, še |izražanje, prikazovanje|; e-mail: e-pošta, elektronska pošta; ekstremen: skrajen, pretiran; ekspedicija: odpošiljanje, odprava; faktor dejavnik; mat. množenec, množitelj; fleksibilen: spremenljiv, nestalen, fleksibílnost spremenljivost, nestalnost; fluktuacija: spreminjanje, gibanje; še |menjavanje zaposlitve|; impresija čutni vtis, še |umetniško delo|; informacija: obvestilo; informativen: poročevalen, obveščevalen, obvestilen; interesanten: zanimiv, primeren, sprejemljiv; internet medmrě̌je; karakter: značaj; komunikacija: sporočanje, sporazumevanje, komunikativen: prilagodljiv, družaben; razumljiv, dojemljiv; konflikt: nasprotje, napetost, nesoglasje; konvencija: pogodba, sporazum; kreativen: ustvarjalen; kriminaliteta: hudodelstvo, kazniva dejanja; kvaliteten: dober, kakovosten; lokalno: krajevno; menedžer: poslovodski upravljavec; vodja; novela: sprememba, dopolnilo, še |krajše pripovedno delo|; operativen: uspešen, zavzet; organizirati: urediti; dobiti, priskrbeti; orientacija: usmerjenost, naravnanost; originalen: izviren, prvoten, prvi; parlament: skupščina; premier: predsednik vlade; profesionalen: strokoven, kakovosten; produkt: proizvod (izdelek, pridelek; reagirati: odgovoriti, odzvati se; redakcija: uredništvo; regija: področje, območje, predel; režim: red, ureditev; rubrika: razpredelek, razdelek, stolpec; ruralen: kmetijski, poljedelski, kmečki, podeželski; servis: začetni udarec (̌̌port), še |delavnica; tehnični pregled|, (popravljalnica) strojev; solidaren: složen, povezan; singel: mala (gramofonska) plošča; startati: nastopiti, začeti tekmovati; status: pravni 
položaj; términ izraz, beseda, termín rok; vikend: počitniška hišica; konec tedna; vikendaš: lastnik počitniške hišic.

4.2.2 Označeno ležeče v okroglem oklepaju (ležeče) in pomeni enakovredno domačo vzporednico: debatirati: (razpravljati); debata: (razpravljanje, razprava); konkurenca: (tekmovalnost pri trženju); partner: (sodelavec).

4.2.3 Označeno ležeče v lomljenem oklepaju <ležeče $>$ in pomeni manj navadno domačo vzporednico prevzeti besedi: donacija: <podaritev, darovanje>; reforma: <prenova>; hipodrom: <konjsko dirkališče $>$.

4.2.4 Označeno pokončno med navpičnicama |pokončno| in pomeni samo splošno pomensko uvrstitev: aretirati: |prijeti, odvzeti prostost $\mid$; atentat: |napad|; avizo: |uvodna glasba|; bejbi.. |otrok, mladič|; delegacija: |odposlanstvo, zastopstvo|; demonstracija: |izražanje, prikazovanje| še predstavitev, prikaz; disciplina: |mir, red|; |panoga, področje|; etnija: |narod, pleme|; fantastičen: |izredno dober|; fenomenalen: |izredno dober|; fluktuacija: |menjavanje zaposlitve|, še spreminjanje, gibanje; funkcija: |položaj, naloga, vloga|; hit: |popularna popevka|; idila: |idealno družinsko življenje|; impresija: |umetniško delo|, še čutni vtis bejbi.. |otrok, mladič|; inženiring: |organiziranje, opravljanje del; podjetje|; kariera: |uveljavitev, uspeh|; katastrofa: |nesreča, pred propadom, uničenjem, smrt|; kolegij: |strokovna združba|; |sestanek, posvet|; komentar: |sestavek, razlaga, pojasnilo, mnenje, stališče|, glag. komentirati ni zapisan; kompleks: |skupina industrijskih stavb; skupek; občutek|; |mnenje, stališče|; kvintet: |petčlanski ansambel|; lokacija: |določen prostor za gradnjo|, |umestitev|; monsinjor: |zaslužni duhovnik|; novela: |krajše pripovedno delo|, še sprememba, dopolnilo; radar: |naprava|; resor: |delovno področje|; rokenrol: |ples|; solo |ne v zboru| (ni v pomenu 'sam'); servis: |delavnica; tehnični pregled|; (popravljalnica) strojev; začetni udarec (šport) (ni v pomenu 'služba/usluga'); sold: |ves denar|; status: pravni položaj; rap: |bitovska zabavna glasba|; terminal: |kraj z objekti za sprejem ali pretovarjanje na začetku ali na koncu prometne poti|; tragičen: |zelo neugoden, slab|.

4.2.5 Kot peta skupina je dodana skupina tujk, ki so prav tako močno vpete v naš jezikovni sistem, a v SP 2001 nimajo niti splošne pomenske uvrstitve: agencija, blok, blues, film, grafik, ilustrator, mikrofon, policist/policijski, profesorica, radio, realizacija, simfonik, spektakel, socialističen, spektakel, stadion, studio, telefon/telefonski, televizija, temperatura, univerziteten.

\subsection{Ugotovitve}

Pregledano gradivo je ponudilo dvoje ugotovitev: (1) pri reproduktivnem govoru (branju, v glavnem poročil, obvestil) je raba tujk na obeh radijskih postajah dokaj enaka, saj oboji predstavljajo iste dnevnoinformativne teme. Razlika 
postane očitna pri spontanem govoru (glede na pogostost rabe), in sicer je na komercialni radijski postaji City zaslediti več izposojenk (po Snoju), tj. v večini stilno zaznamovanih prevzetih besed (pubec za pokr. štaj. fant, deček; čao za sleng. na svidenje, zbogom), na nacionalni postaji Radio Maribor pa več tujk (po Snoju). Nacionalna radijska postaja namreč obravnava zahtevnejše teme, cilja na zahtevnejše občinstvo, posledično so zahtevnejši tudi sogovorci, naj bo to v studiu, preko telefona, na terenu ...; (2) namen raziskave nikakor ni preganjati tujke izključno zaradi njihovega izvora, sploh tistih ne, za katere nimamo ustreznih slovenskih besed. To bi vsekakor vodilo v siromašenje slovenskega jezika samega. Vsekakor pa želi izpostaviti pomen sprejemanja pojmovnega sveta prek domačega jezika, posebej v medijih, ki so javno dostopni vsem in morajo ciljno publiko enapravno informirati. Hkrati pa bi poenotena merila za vključevanje pri uvrščanju med slovenske vzporednice v priročnikih in pri normiranju bila $\mathrm{v}$ veliko pomoč uporabnikom, predvsem prevajalcem, lektorjem v gledališču, pri filmu, televiziji in radiu (govorcem/piscem v medijih), igralcem in vsem, ki se ukvarjajo z jezikom. Ob pregledu se zastavlja vprašanje ustreznosti uvrščenosti posamezne tujke med t. i nevtralno ali navadnejšo dvojnico, enakovredno domačo vzporednic, manj navadno domačo vzporednico ali zgolj med samo splošno pomensko uvrstitev. Kako lahko torej učečemu se slovenščine pojasnimo, zakaj tujka disciplina: |mir, red|; |panoga, področje| spada v skupino samo splošna pomenska uvrstitev, ne pa, kot adaptacija: prilagoditev, prilagajanje, v skupino nevtralna ali navadnejša dvojnica. Neusklajenost se kaže tudi pri pojasnjevanju pomena posameznih besednih vrst znotraj iste besedne družine, kot nam kaže primer: sam.: ekstrém -a m, pojm. (ẹ) izogibati se ov skrajnosti, pretiranosti kot nevtralna ali navadnejša dvojnica; prid.: ekstrémen -mna -o; -ejši -a -e (ẹ; ẹ) skrajen, pretiran tudi kot nevtralna ali navadnejša dvojnica; prisl.: ekstrémno mer. prisl. -ej(š)e (ẹ; ẹ) poud. težka plezalna smer|izjemno, zelo| pa kot samo splošna pomenska uvrstitev.

Enotnost meril bi lahko veliko pripomogla tudi pri tvorjenju slovenskega strokovnega izrazja, ki zaradi (včasih tudi zaradi ležernosti ali neznanja) prevzemanja tujk izgublja svojo pomembno vlogo. Hkrati pa bi poenotenje nedvomno prispevalo tudi k nastanku slovarja sinonimov. Le s takšnim pristopom lahko osvetlimo moč tvorbenih in izraznih sposobnosti slovenskega jezika.

\section{LITERATURA}

France BEZLAJ, 1967: Eseji o slovenskem jeziku. Ljubljana: Mladinska knjiga.

Claude HAGEGE, 2005: Zaustaviti izumiranje jezikâ. Zagreb: Disput.

Monika KALIN GOLOB, 2008: Jezikovnokulturni pristop h knjižni slovenščini. Ljubljana: Fakulteta za družbene vede.

Ludvik KALUŽA, 1977/78: Govor na Radiu Ljubljana (shematični prikaz). Jezik in slovstvo 23/1 (oktober), 21-23. 
Lidija KOSI, 2000: Govorni del radijskega programa na nacionalni radijski postaj. Magistrsko delo. Ljubljana: [L. Kosi].

Tomo KOROŠEC, Janez DULAR, 1985: Jezikovna kultura in jezikovna politika. Slovenski jezik 4. Maribor: Založba Obzorja.

Vesna MILDNER, 2000: Stavovi prema hrvatskim govornim varietetima. Jezička norma i varieteti. Zbornik (Opatija 1998). Ur. Boris Pritchard ... [et al.]. Zagreb, Rijeka: Hrvatsko društvo za primijenjenu lingvistiku,349-366.

Martina OROŽEN 2003: Razvoj slovenske jezikoslovne misli. Maribor: Slavistično društvo Maribor. (Zora, 26).

Polona PIVEC, 2003: Pragmatične pretvorbe v radijskem sporočanju. Magistrsko delo. Ljubljana: [P. Pivec].

Eva SICHERL, 1999: The English element in contemporary standard Slovene: phonological, morphological and semantic aspects. Ljubljana: Znanstveni inštitut Filozofske fakultete.

Marko SNOJ, 1997: Slovenski etimološki slovar. Ljubljana: Mladinska knjiga. (Zbirka Cicero).

- -, 2005: O prevzetih besedah, tujkah in izposojenkah. Slovenski jezik. Št. 5, [113]-122.

Cvetka ŠERUGA PREK in E. ANTONČIČ, 2003: Slovenska zborna izreka. Maribor: Aristej.

Ivo ŠKARIĆ, 1982: U potrazi za izgubljenim govorom. Zagreb: Školska knjiga.

George THOMAS: Linguistic purism. London, New York: Longman (Studies in language and linguistics).

Hotimir TIVADAR, 2008: Pravorečje, knjižni jezik in mediji. Slovenski jezik, literatura, kultura in mediji / 44. seminar slovenskega jezika, literature in kulture, 23. 6.-11. 7. 2008. Ljubljana: Center za slovenščino kot drugi/tuji jezik pri Oddelku za slovenistiko Filozofske fakultete. 24-35.

Jože TOPORIŠIČ, 1992: Enciklopedija slovenskega jezika. Ljubljana.

- -, 2000: Slovenska slovnica. Maribor: Založba Obzorja.

-- (ur.), 2001: Slovenski pravopis. Ljubljana: ZRC SAZU.

--, 2006: Besedjeslovne razprave. Ljubljana: ZRC SAZU, 2006 (Zbirka Linguistica et philologica, 13). 62-63.

Alenka VALH LOPERT: 2007: Germanismen in der Sprache des kommerziallen Radiosenders Radio City Maribor. 10. Arbeitstagung für bayerisch-österreichische Dialektologe, an der Alpen-Adria-Universität Klagenfurt, vom 19. bis 22. September 2007. Zusammenfassungen. Klagenfurt: Institut für Sprachwissenschaft und Computerlinguistik der Universität Klagenfurt. (V tisku.)

- -, 2008: Prevzeto besedje v jeziku komercialne radijske postaje (Radio City v Mariboru). Jezikoslovni zapiski, 14, št. 1, str. 123-137.

Zakon o medijih: Uradni list 35/2001, 11. 5. 2001 (stran 4017). Dostopno: http://www. uradni-list.si/1/objava.jsp?urlid=200135\&stevilka=2043. 
Nada ZGRABLJIĆ ROTAR, 2007: Radio: mit i informacija, dijalog i demokracija. Zagreb.

Jagoda GRANIĆ, 2006: Novi »razrađeni« mediji i »ograničeni« kodovi. Jezik $i$ mediji. Jedan jezik: više svjetova. Zbornik. Zagreb, Split. 267-278.

\section{USE OF FOREIGN WORDS IN MARIBOR SPOKEN MEDIA}

This article examines the foreign words used by professional announcers (34) in their prepared and non-prepared (spontaneous) speech on two radio stations in Maribor, the national broadcaster (Radio Maribor) and the commercial channel (Radio CITY). The first part defines the origins of words used according to the Slovene Etymological Dictionary by M. Snoj, such as radar from English Ra(dio) D(etecting) A(nd) R(anging); stadion from German Stadion; and solidaren from French solidaire (from Lat., in solido). In the second part, possible Slovene equivalents which are no longer stylistically marked are suggested: (1) neutral or common doublet sdebatirati > razpravljati; (2) adequate equivalents originalen $>$ izviren, prvoten, prvi or (3) less usual equivalents reforma $>$ prenova. The analysis shows that many foreign words could be replaced by appropriate Slovene doublets (trend - težnja, usmeritev; akter-povzročitelj, ustvarjalec), but nonetheless, some should remain as they have no Slovene equivalents (scenarij, demokracija). The analysis leads to the following conclusion: on the commercial radio station, professional announcers use fewer foreign words in their spontaneous speech than announcers on the national radio. The choice depends on their interlocutors (in the studio, on the radio) and even more so on the topic of the conversation. On the other hand, there are almost no differences in their prepared speech. 